\title{
Improving Intestinal Amino Acid Supply of Pre- and Postpartum Dairy Cows with Rumen-Protected Methionine and Lysine ${ }^{\star} \dagger$
}

\author{
M. T. Socha, ${ }^{1}$ D. E. Putnam, ${ }^{2}$ B. D. Garthwaite,${ }^{3}$ N. L. Whitehouse,${ }^{4}$ N. A. Kierstead, ${ }^{4}$ \\ C. G. Schwab, ${ }^{4}$ G. A. Ducharme, ${ }^{5}$ and J. C. Robert ${ }^{6}$ \\ ${ }^{1}$ Zinpro Corporation, Eden Prairie, MN 55374 \\ ${ }^{2}$ Balchem Corporation, Slate Hill, NY 10973 \\ ${ }^{3}$ Bloomington, MN 55437 \\ ${ }^{4}$ Department of Animal and Nutritional Sciences, University of New Hampshire, Durham 03824 \\ ${ }^{5}$ Agrimedia Communications, Atlanta, GA 30324 \\ ${ }^{6}$ Adisseo, Commentry, France
}

\section{ABSTRACT}

Eighty-four Holstein cows were assigned to a randomized block experiment to determine effects of supplementing pre- and postpartum diets containing highLys protein supplements with rumen-protected Met and Lys. Before parturition, cows received a basal diet with 1) no rumen-protected amino acids (AA), 2) 10.5 $\mathrm{g} / \mathrm{d}$ of Met from rumen-protected Met, or 3) $10.2 \mathrm{~g} / \mathrm{d}$ of Met and $16.0 \mathrm{~g} / \mathrm{d}$ of Lys from rumen-protected Met plus Lys. After parturition, cows continued to receive AA treatments but switched to diets balanced for 16.0 or $18.5 \%$ crude protein (CP). Diets were corn-based; supplemental protein was provided by soybean products and blood meal. Cows received treatments through d 105 of lactation. Compared with basal and Met-supplemented diets, Met + Lys supplementation increased yield of energy-corrected milk, fat, and protein, and tended to increase production of $3.5 \%$ fat-corrected milk. Significant $\mathrm{CP} \times \mathrm{AA}$ interactions were observed only for milk protein and fat content. Supplementation of the 16\% CP diet with Met and Met + Lys had no effect on milk true protein and fat content. However, Met and Met + Lys supplementation of the 18.5\% CP diet increased milk protein content by 0.21 and 0.14 percentage units, respectively, and Met supplementation increased fat content by 0.26 percentage units. Results of this study indicate that early-lactation cows fed corn-based diets are responsive to increased intestinal supplies of Lys and Met and that the responses depend on dietary CP concentration, supply of metabo-

Received February 18, 2004

Accepted July 15, 2004.

Corresponding author: Mike Socha; e-mail: msocha@zinpro.com.

*Scientific Contribution Number 1903 from the New Hampshire Agricultural Experiment Station.

$\dagger$ This study was supported by NC-185 (currently NC-1009) Cooperative Regional Research Project, "Metabolic Relationships in Supply of Nutrients for Lactating Cows," and by a grant from Adisseo, Antony, France. lizable protein, and intestinal digestibility of the rumen-undegradable fraction of supplemental proteins. (Key words: rumen-protected amino acids, lysine, methionine, lactating cow)

Abbreviation key: ECM = energy-corrected milk, $\mathbf{M P}=$ metabolizable protein $; \mathbf{R P A A}=$ rumen-protected AA, RPMet = rumen-protected Met, RPMet+Lys = rumen-protected Met plus Lys, $\mathbf{1 6 B}=16.0 \% \mathrm{CP}$ basal diet, $\mathbf{1 6 M}=16.0 \% \mathrm{CP}$ diet with $10.5 \mathrm{~g}$ of Met from rumen-protected Met, $\mathbf{1 6 M L}=16.0 \% \mathrm{CP}$ diet with 10.2 $\mathrm{g}$ of Met and $16.0 \mathrm{~g}$ of Lys from rumen-protected Met and rumen-protected Met plus Lys, 18.5B $=18.5 \% \mathrm{CP}$ basal diet, 18.5M $=18.5 \% \mathrm{CP}$ diet with $10.5 \mathrm{~g}$ of Met from rumen-protected Met, 18.5ML $=18.5 \% \mathrm{CP}$ diet with $10.2 \mathrm{~g}$ of Met and $16.0 \mathrm{~g}$ of Lys from rumen-protected Met and rumen-protected Met plus Lys.

\section{INTRODUCTION}

Production responses of dairy cows to improved Lys and Met nutrition include variable increases in feed intake, milk production, and content and yield of milk protein. Literature summaries confirm that responses to postruminal Lys and Met supplementation are greater when basal levels of Lys and Met in RUP are low rather than high, when RUP supplies a greater portion of the metabolizable protein (MP), when cows are in early rather than mid or late lactation, and in high-producing cows rather than low producing cows (Rulquin and Vérité, 1993; NRC, 2001). There are 4 additional and noteworthy observations regarding improvements in duodenal concentrations of Lys and Met. First, content of milk protein is more sensitive than milk yield (Rulquin et al., 1993; NRC, 2001). Second, results of several experiments indicate that milk casein is affected more than the whey and NPN fractions (Donkin et al., 1989; Chow et al., 1990; Le Henaff et al., 1990; Armentano et al., 1993). Third, increases in content of milk protein are greater than what would be expected 
by increasing dietary CP (NRC, 2001). Finally, increases in milk yield to supplemental Lys and Met generally are limited to cows in early lactation when the need for absorbable AA, relative to absorbable energy, is greatest (Polan et al., 1991; Schwab et al., 1992a,b; Rulquin and Vérité, 1993).

The advantage of improving the balance of absorbable AA is the increased efficiency of use of absorbed AA for milk protein production. It has been demonstrated that improved Lys and Met nutrition reduced the amount of dietary CP needed to achieve similar yields of milk protein (Robert et al., 1989; Rulquin et al., 1990).

In most of the studies referred to above, a Latin Square with short experimental periods (generally 2 wk or less) was used as the experimental design, and in only a few experiments (Overton et al., 1996; Carson et al., 1998; Xu et al., 1998) did cows receive supplemental AA before or immediately after calving. The objectives of this study were: 1) to determine the effects of supplementing corn-based diets of prepartum and early postpartum cows with rumen-protected Met (RPMet) and rumen-protected Met plus Lys (RPMet+Lys) on early lactation performance, 2) to determine if the use of high-Lys protein supplements provided adequate intestinal supplies of Lys, and 3) to determine the effect of postpartum dietary $\mathrm{CP}$ on response to rumen-protected AA (RPAA) supplementation.

\section{MATERIALS AND METHODS}

\section{Experimental Design and Treatments}

Eighty-four multiparous cows, blocked by calving date (14 blocks), were assigned to an experiment using a randomized complete block design, $14 \mathrm{~d}$ before expected calving. The experiment consisted of 3 prepartum diets and 6 postpartum diets. The 3 prepartum diets were the basal diet, the basal diet supplemented with $15 \mathrm{~g} /$ $\mathrm{d}$ of Smartamine M (Adisseo, Atlanta, GA) which supplied $10.5 \mathrm{~g}$ of Met, or the basal diet supplemented with $6 \mathrm{~g} / \mathrm{d}$ of Smartamine M plus $40 \mathrm{~g} / \mathrm{d}$ of Smartamine ML (Adisseo), which together supplied $10.2 \mathrm{~g}$ of Met and $16.0 \mathrm{~g}$ of Lys (Table 1). At calving, cows continued to receive their respective RPAA treatment, in similar amounts, but were switched to either a 16.0 or $18.5 \%$ $\mathrm{CP}$ postcalving diet (Table 1 ), forming a $2 \times 3$ factorial arrangement of treatments during lactation. The 6 lactation treatments were the $16.0 \% \mathrm{CP}$ basal diet (16B), 16B diet supplemented with RPMet (16M), the 16B supplemented with RPMet+Lys (16ML), the $18.5 \% \mathrm{CP}$ basal diet (18B), the 18B supplemented with RPMet (18M), and the 18B supplemented with RPMet+Lys (18ML). Cows remained on their assigned diets through wk 15 of lactation. All procedures related to animal care were conducted with the approval of the University
Table 1. Ingredient composition of basal diets.

\begin{tabular}{|c|c|c|c|}
\hline \multirow[b]{2}{*}{ Ingredient, \% DM } & \multicolumn{3}{|c|}{ Diet } \\
\hline & Precalving & $\begin{array}{l}18.5 \% \\
\mathrm{CP}\end{array}$ & $\begin{array}{l}16.0 \% \\
\mathrm{CP}\end{array}$ \\
\hline Corn silage $^{1}$ & 31.1 & 22.3 & 22.3 \\
\hline Grass-legume silage, mid-mat. & 16.7 & 12.6 & 12.6 \\
\hline Alfalfa hay, mid-mat. & 7.2 & 9.7 & 9.7 \\
\hline Corn, coarse grind & 32.0 & 31.8 & 37.1 \\
\hline Soybean meal, solvent-extracted & 6.9 & 11.5 & 0.8 \\
\hline Raw soybeans, cracked & 2.8 & 5.3 & 5.3 \\
\hline Soybean meal, expeller ${ }^{2}$ & 0.0 & 0.0 & 5.3 \\
\hline Blood meal, ring-dried & 0.7 & 1.4 & 1.4 \\
\hline $\mathrm{Fat}^{3} \mathrm{Ha}$ & 0.7 & 1.4 & 1.4 \\
\hline Mineral-vitamin $\operatorname{mix}^{4}$ & 1.9 & 4.0 & 4.0 \\
\hline
\end{tabular}

${ }^{1}$ Treated at ensiling with $0.5 \%$ urea.

${ }^{2}$ SoyPlus (West Central Co-op, Ralston, IA).

${ }^{3}$ Alifet (Alifet USA, Inc., Cincinnati, OH).

${ }^{4}$ Mineral-vitamin mix composition: $15.5 \% \mathrm{Ca}, 5.6 \% \mathrm{P}, 4.6 \% \mathrm{Mg}$, $1.5 \% \mathrm{~K}, 2.1 \% \mathrm{~S}, 0.2 \% \mathrm{Zn}, 0.13 \% \mathrm{Mn}, 0.04 \% \mathrm{Cu}, 0.23 \% \mathrm{Fe}, 0.0025 \%$ I, $0.0041 \%$ Co, $0.0013 \%$ Se, 143,424 IU/kg of vitamin A, 45,895 IU/ $\mathrm{kg}$ of vitamin D, and $457 \mathrm{IU} / \mathrm{kg}$ of vitamin $\mathrm{E}$.

of New Hampshire Institutional Animal Care and Use Committee.

\section{Feeding and Management of Cows}

Diets (Table 1) were fed as a TMR and were prepared by weighing each ingredient and blending in a drumtype mixer (Data Ranger; American Calan, Inc., Northwood, NH). Alfalfa hay was chopped before incorporation into the TMR using a bale chopper (model 6-90, Wic Inc., Johnson, Quebec, Canada). Cows were fed $67 \%$ of the total daily allotment at $1530 \mathrm{~h}$ and $33 \%$ of the daily allotment at $0530 \mathrm{~h}$. Feed allotments were adjusted to achieve 5 to $10 \%$ orts. Orts were collected at $1300 \mathrm{~h}$. The RPAA supplements were top dressed at time of feeding. Before initiation of the experiment, and every 4 wk thereafter, feed ingredients were analyzed for $\mathrm{CP}, \mathrm{NDF}, \mathrm{ADF}$, ether extract, $\mathrm{Ca}, \mathrm{P}, \mathrm{K}, \mathrm{Mg}$, and $\mathrm{S}$ (Dairy One Forage Laboratory, Ithaca, NY). Forage to grain ratio was adjusted to maintain a forage NDF of $21 \%$ of DM. Amounts of corn and expeller form of soybean meal (SoyPlus, West Central Co-op, Ralston, IA) were altered to achieve a CP level of $16.0 \%$ for the $16.0 \%$ CP diets. For the $18.5 \%$ CP diets, amounts of corn and solvent soybean meal were altered to achieve a CP level of $18.5 \%$.

\section{Measurements, Collection, and Analysis of Samples}

Feed ingredients and orts were sampled weekly, analyzed for DM $\left(60^{\circ} \mathrm{C}\right.$ under $760 \mathrm{~mm}$ of vacuum for 24 h), ground to pass through a 1-mm screen, and then composited across experiment by treatment. The orts were composited by treatment and analyzed for CP, 
Table 2. Chemical composition of feeds used in pre- and postpartum diets.

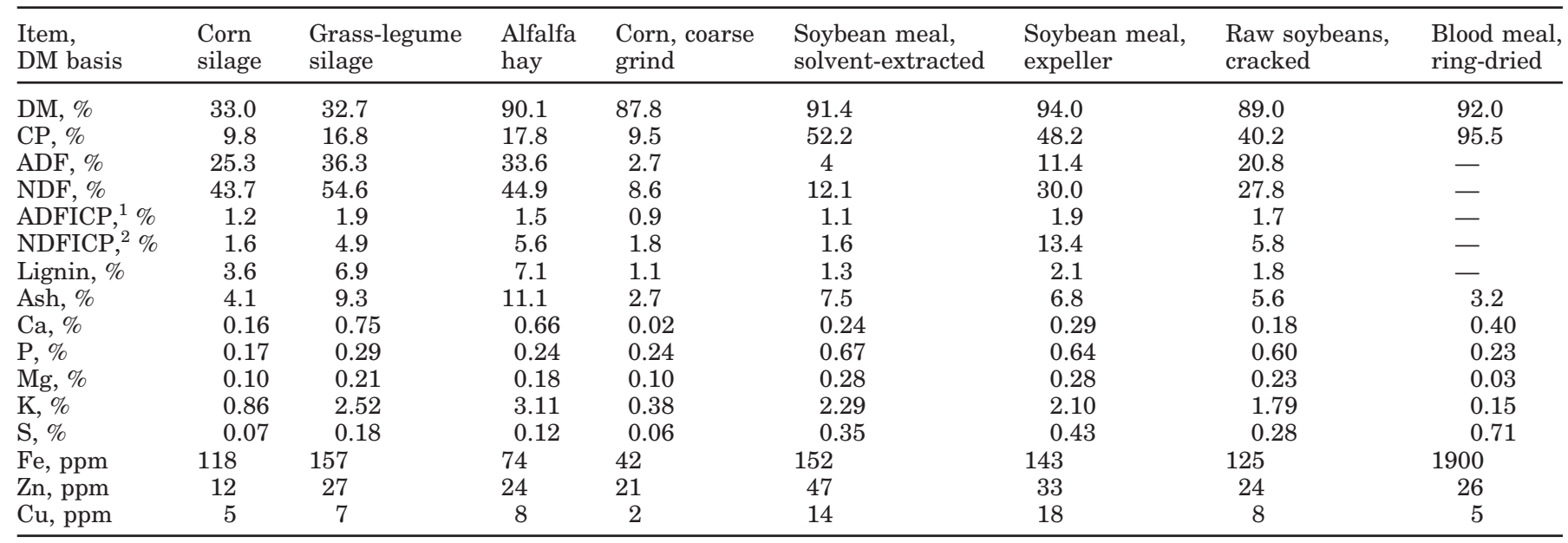

${ }^{1} \mathrm{ADFICP}=$ Acid detergent insoluble $\mathrm{CP}$

${ }^{2} \mathrm{NDFICP}=$ Neutral detergent insoluble CP.

$\mathrm{NDF}, \mathrm{ADF}$, ether extract, $\mathrm{Ca}, \mathrm{P}, \mathrm{K}, \mathrm{Mg}$, and S (Dairy One Forage Laboratory, Ithaca, NY). Composited samples of feed ingredients and orts were analyzed for AA concentrations using procedures described by Putnam et al. (1997). Composited samples of blood meal and expeller soybean meal were analyzed for RUP digestibility at the University of Minnesota using the 3-step procedure of Calsamiglia and Stern (1995).

Milk weights were recorded twice daily; milk samples were taken from 2 consecutive milkings each week. Milk samples were preserved with 2-bromo-2-nitropropane-1,3 diol and analyzed for fat and true protein by Dairy One Forage Laboratory (Ithaca, NY) using infrared technology. Body condition scores were obtained weekly by 3 individuals and averaged. Cows in blocks 1 through 12 were weighed daily. Body weights for the complete duration of the study were not available for cows in blocks 13 and 14, due to mechanical failure of the scale.

Blood samples were obtained by venipuncture of the coccygeal vein at approximately $2 \mathrm{~h}$ after the morning feeding during wk 1, 2, 3, 4, and 8 of lactation. Blood was collected into one $10-\mathrm{mL}$ evacuated tube containing no additive and one $10-\mathrm{mL}$ evacuated tube containing sodium heparin and $4 \%$ sodium fluoride (Vacutainer, Becton Dickinson, Rutherford, NJ). Tubes containing the anticoagulant were placed in an ice bath until centrifuged at $3300 \times \mathrm{g}$ for $20 \mathrm{~min}$ at $5^{\circ} \mathrm{C}$. One aliquot of plasma was removed and frozen $\left(-20^{\circ} \mathrm{C}\right)$ for determination of glucose (Sigma kit Trinder 500, Sigma Chemical Co., St. Louis, MO) (Barham and Trinder, 1972) and NEFA (WAKO NEFA C kit, WAKO Chemicals USA, Inc., Richmond, VA) (Johnson and Peters, 1993) concentrations. An additional aliquot was deproteinized; 4 vol- umes were vortexed with 1 volume of $15 \%$ sulfosalicylic acid, centrifuged at $3300 \times g$ for $20 \mathrm{~min}$ at $5^{\circ} \mathrm{C}$, and the supernatant frozen $\left(-20^{\circ} \mathrm{C}\right)$ for BHBA analysis (Gibbard and Watkins, 1968). Blood in tubes containing no additive was allowed to clot at room temperature (15 to $\left.21^{\circ} \mathrm{C}\right)$, centrifuged $(3300 \times g$ for $20 \mathrm{~min})$, and the serum was frozen for determination of urea concentrations (Sigma kit 640, Sigma Chemical Co.) (Crocker, 1967). All plasma and serum samples were thawed at $5^{\circ} \mathrm{C}$ before analysis.

\section{Statistical Analysis and Calculations}

Production data were analyzed using the MIXED procedure of SAS (SAS Institute, 1999) according to the following model:

$$
\begin{aligned}
\mathrm{Y}_{\mathrm{ijkl}}= & \mu+\mathrm{A}_{\mathrm{i}}+\mathrm{P}_{\mathrm{j}}+\mathrm{AP}_{\mathrm{ij}}+\beta \mathrm{X}_{\mathrm{ijk}}+c_{\mathrm{kij}}+\mathrm{T}_{1} \\
& +\mathrm{AT}_{\mathrm{il}}+\mathrm{PT}_{\mathrm{jl}}+\mathrm{APT}_{\mathrm{ijl}}+\mathrm{E}_{\mathrm{ijkl}}
\end{aligned}
$$

where $Y_{i j k l}$ is the dependent, continuous variable, $\mu$ is the overall mean, $A_{i}$ is the fixed effect of the ith level of AA ( $i=1, \ldots, 3), P_{j}$ is the fixed effect of the jth level of protein $(j=1,2), \beta$ is the regression coefficient, $X_{i j k}$ is the covariate measurement, $\mathrm{c}_{\mathrm{kij}}$ is the random effect of the kth cow with the ijth treatment subclass $(\mathrm{k}=1$, ..., 14), $\mathrm{T}_{1}$ is the fixed effect of the lth week of experiment $(l=1, \ldots, 15), E_{i j k l}$ is the residual error, and $\mathrm{AP}_{\mathrm{ij}}, \mathrm{AT}_{\mathrm{il}}$, $\mathrm{PT}_{\mathrm{jl}}$, and $\mathrm{APT}_{\mathrm{ijl}}$ are fixed effects due to the interactions of the main effects.

In this model, the random effect of cows within treatment subclasses is used as the error term for the effect of AA and protein levels and their interactions. Residual errors, which are errors within cows across time and 
Table 3. Amino acid composition of feeds used in pre- and postpartum diets.

\begin{tabular}{lllrrrrrr}
\hline $\begin{array}{l}\text { AA, } \\
\text { \% of CP }\end{array}$ & $\begin{array}{l}\text { Corn } \\
\text { silage }\end{array}$ & $\begin{array}{l}\text { Grass- } \\
\text { legume } \\
\text { silage }\end{array}$ & $\begin{array}{l}\text { Alfalfa } \\
\text { hay }\end{array}$ & $\begin{array}{l}\text { Corn, } \\
\text { coarse } \\
\text { grind }\end{array}$ & $\begin{array}{l}\text { Soybean meal, } \\
\text { solvent- } \\
\text { extracted }\end{array}$ & $\begin{array}{l}\text { Soybean } \\
\text { meal, } \\
\text { expeller }\end{array}$ & $\begin{array}{l}\text { Raw } \\
\text { soybeans, } \\
\text { cracked }\end{array}$ & $\begin{array}{l}\text { Blood } \\
\text { meal, } \\
\text { ring-dried }\end{array}$ \\
\hline Ala & 7.96 & 6.43 & 4.10 & 7.68 & 4.02 & 3.92 & 4.38 & 6.95 \\
Asp & 4.80 & 7.26 & 11.46 & 7.47 & 10.57 & 10.25 & 11.32 & 8.77 \\
Cys & 1.53 & 1.55 & 0.28 & 2.21 & 1.15 & 1.12 & 1.12 & 0.02 \\
Glu & 9.69 & 7.02 & 10.11 & 18.63 & 16.59 & 15.73 & 17.51 & 8.07 \\
Gly & 3.27 & 4.05 & 5.06 & 4.00 & 3.85 & 3.78 & 4.18 & 3.92 \\
Ser & 2.86 & 3.10 & 4.89 & 4.74 & 4.41 & 4.40 & 4.80 & 4.59 \\
Tyr & 2.14 & 2.44 & 3.82 & 3.89 & 3.05 & 2.95 & 3.41 & 2.73 \\
Arg & 1.84 & 2.62 & 4.61 & 4.74 & 6.67 & 6.06 & 7.19 & 3.70 \\
His & 1.33 & 1.37 & 2.25 & 2.74 & 2.36 & 2.24 & 2.56 & 4.73 \\
Ile & 2.65 & 3.21 & 3.88 & 3.16 & 3.75 & 3.36 & 4.18 & 0.94 \\
Leu & 7.55 & 6.37 & 8.20 & 12.32 & 6.88 & 6.64 & 7.56 & 10.44 \\
Lys & 2.14 & 3.63 & 4.83 & 3.16 & 5.65 & 4.75 & 6.19 & 7.70 \\
Met & 1.02 & 0.95 & 0.84 & 1.79 & 0.92 & 0.89 & 1.09 & 1.48 \\
Phe & 2.86 & 3.63 & 5.06 & 4.84 & 4.35 & 4.13 & 4.80 & 5.87 \\
Thr & 2.65 & 3.27 & 4.55 & 3.68 & 3.58 & 3.57 & 3.88 & 4.41 \\
Val & 3.98 & 4.76 & 6.80 & 4.84 & 4.21 & 3.88 & 4.65 & 7.35 \\
\hline
\end{tabular}

represent errors from repeated measurements from the experimental units (cows), were modeled using a firstorder autoregressive covariance structure. Degrees of freedom were calculated using the Kenward-Roger option of the MIXED procedure (SAS Institute, 1999). A covariate term was included in the model to reduce the variance due to cow within treatment subclasses. The covariate variables were taken from the prior lactation of each cow and consisted of mature equivalents for milk production, milk component yields, or milk composition, as appropriate. The cows had not been assigned to an experiment in their previous lactation. Mature equivalent milk production was used as the covariate for DMI analysis. The covariate term was removed from the final statistical model in the analysis of BW, blood, and prepartum DMI data because analyzing the data without covariates resulted in smaller Bayesian information criteria values. Block effect was initially included in the model but was removed in the final analysis because it was found to be insignificant. Least square means were determined for AA source, protein level, and the interaction between AA source and protein level. The DIFF option in SAS was used to test treatment differences among least square means. Significant treatment responses were declared at $P \leq 0.05$ and trends for treatment responses were declared at $P$ $>0.05$ but $P \leq 0.15$.

The Univariate Procedure of SAS (SAS Institute, 1999) was used to determine outlier cows for DM intake during the prepartum period. An observation that was greater than 2.5 standard deviations $(\mathrm{SD}=2.97)$ from the mean (mean $=14.66$ ) for the last $7 \mathrm{~d}$ of gestation was considered an outlier. The results of the outlier analysis indicated that 2 cows were outliers due to extremely low $(5.7 \mathrm{~kg} / \mathrm{d})$ and extremely high $(25.1 \mathrm{~kg} / \mathrm{d})$
DMI; therefore these cows were removed from the final statistical analysis.

\section{RESULTS}

The average time required to complete a block was $6.4 \mathrm{wk}$ (range: 3 to $11 \mathrm{wk}$ ). The length of the experiment from the time the first cow was assigned to treatment until the last cow completed the experiment was 535 d. The RPAA supplements were readily consumed by the cows with no cows refusing to eat the supplements. Four cows were removed from the experiment; 3 due to the development of pendulous udders which hindered milking of the cows, and 1 because of an immobilizing calving injury. Information collected on these cows was not included in the statistical analysis of the data.

\section{Chemical Composition of Ingredients and Diets}

The chemical and AA compositions of feed ingredients are shown in Tables 2 and 3. The measured RUP digestibility coefficients for expeller soybean meal and blood meal were 92.8 and $60.7 \%$, respectively.

The chemical compositions of the consumed diets are shown in Table 4. The chemical composition of the consumed diet was calculated by measuring the concentrations of chemical components in each ingredient and in orts, and subtracting the amount of each chemical component in orts from the total amount of each chemical component offered. Based upon average milk production, milk composition, and DMI for the 15 -wk postpartum experimental period (Table 5), the RDP, RUP, and metabolizable protein (MP) balances as predicted by NRC (2001) were $-183,-205$, and $-165 \mathrm{~g} / \mathrm{d}$, respectively, for cows fed 16B; and 352,11 , and $9 \mathrm{~g} / \mathrm{d}$, respec- 
Table 4. NRC (2001) evaluation of the basal diets. ${ }^{1}$

\begin{tabular}{|c|c|c|c|}
\hline \multirow[b]{2}{*}{ Chemical component } & \multirow{2}{*}{$\begin{array}{l}\text { Precalving } \\
\text { diet }^{2}\end{array}$} & \multicolumn{2}{|c|}{ Lactation $\operatorname{diet}^{3}$} \\
\hline & & $18.5 \% \mathrm{CP}$ & $16.0 \% \mathrm{CP}$ \\
\hline $\mathrm{NDF}, \%$ of DM & 30.9 & 26.6 & 27.4 \\
\hline Forage NDF, $\%$ of DM & 26.5 & 21.0 & 21.0 \\
\hline $\mathrm{RDP}, \%$ of $\mathrm{DM}$ & 10.3 & 11.5 & 9.3 \\
\hline RUP, $\%$ of DM & 5.3 & 7.1 & 6.7 \\
\hline $\mathrm{CP}, \%$ of $\mathrm{DM}$ & 15.6 & 18.5 & 16.0 \\
\hline RDP balance, $\mathrm{g} / \mathrm{d}$ & 0 & 352 & -183 \\
\hline RUP balance, g/d & 826 & 11 & -205 \\
\hline MP balance, ${ }^{4} \mathrm{~g} / \mathrm{d}$ & 628 & 9 & -165 \\
\hline $\mathrm{NE}_{\mathrm{L}}$ balance, $\mathrm{Mcal} / \mathrm{d}$ & 12.5 & -2.5 & -2.5 \\
\hline \multicolumn{4}{|l|}{ Lys, \% of MP } \\
\hline Basal & 6.6 & 6.3 & 6.1 \\
\hline With rumen-protected Met & 6.5 & 6.2 & 6.1 \\
\hline With rumen-protected Met + Lys & 7.5 & 6.7 & 6.5 \\
\hline \multicolumn{4}{|l|}{ Met, \% of MP } \\
\hline Basal & 1.8 & 1.6 & 1.6 \\
\hline With rumen-protected Met & 2.4 & 1.9 & 1.9 \\
\hline With rumen-protected Met + Lys & 2.4 & 1.9 & 1.9 \\
\hline \multicolumn{4}{|l|}{ MP-Lys, g/d } \\
\hline Basal & 101 & 172 & 157 \\
\hline With rumen-protected Met & 101 & 172 & 157 \\
\hline With rumen-protected Met + Lys & 117 & 185 & 170 \\
\hline \multicolumn{4}{|l|}{ MP-Met, g/d } \\
\hline Basal & 27 & 44 & 42 \\
\hline With rumen-protected Met & 37 & 52 & 50 \\
\hline With rumen-protected Met + Lys & 37 & 52 & 50 \\
\hline
\end{tabular}

${ }^{1}$ Diets were evaluated using nutrient profiles listed in Tables 2 and 3. For nutrients and feed components not listed in Tables 2 and 3, default values were used, with the exception of RUP digestibility of blood meal. Analysis of the blood meal using the 3-step procedure of Calsamiglia and Stern (1995) yielded an RUP digestibility value of $60.7 \%$ (lower than the NRC default value of $80 \%$ ).

${ }^{2}$ Animal inputs: Holstein cow, 50 mo of age, $635 \mathrm{~kg}$ of BW, $270 \mathrm{~d}$ pregnant, $15.2 \mathrm{~kg} / \mathrm{d}$ of DMI, and default environmental conditions.

${ }^{3}$ Animal inputs: Holstein cow, 52 mo of age, $630 \mathrm{~kg}$ of BW, 45 DIM, $44.0 \mathrm{~kg} / \mathrm{d}$ of milk, $3.7 \%$ milk fat, $2.9 \%$ milk true protein, $0 \mathrm{~d}$ pregnant, $23.6 \mathrm{~kg} / \mathrm{d}$ of DMI, and default environmental conditions.

${ }^{4} \mathrm{MP}=$ Metabolizable protein.

tively, for cows fed 18.5B (Table 4). Corn sources (silage and grain) supplied 36 and $31 \%$ of dietary RUP for the 16 and $18.5 \%$ CP diets, respectively; the higher Lys feeds, soybean meal, raw soybeans, expeller soybean meal, and blood meal supplied 53 and $58 \%$ of dietary RUP for the 16 and $18.5 \%$ CP diets, respectively.

According to NRC (2001), the predicted percentages of Lys and Met in MP were 6.6 and 1.8; 6.1 and 1.6; and 6.3 and $1.6 \%$ for the precalving basal diet and the 16B and 18.5B diets, respectively (Table 4). These predicted concentrations of Lys and Met in MP are less than the concentrations of 7.2 and $2.4 \%$ suggested to be required for maximum yield and content of milk protein (NRC, 2001). Due to the Lys:Met ratios being well in excess of the optimum of 3.0 (NRC, 2001), diets appeared to be more limiting in Met than Lys.

\section{DMI and Lactation Responses}

There was no effect of treatment $(P>0.15)$ on prepartum DMI (Table 5). Cows receiving RPMet tended to $(P \leq 0.15)$ consume less DM than cows receiving no
RPAA or RPMet+Lys (22.9 vs. 23.7 and $24.3 \mathrm{~kg} / \mathrm{d}$, respectively, Table 5). Supplementing the basal diets with RPMet numerically reduced $(P>0.15)$ milk yield, whereas supplementing with RPMet+Lys numerically increased milk yield; the net result was that cows fed RPMet+Lys produced more $(P \leq 0.05)$ milk than cows fed RPMet (44.9 vs. $41.8 \mathrm{~kg} / \mathrm{d})$. Improving intestinal supply of Lys and Met through feeding RPMet+Lys compared with no RPAA or RPMet supplementation increased $(P \leq 0.05)$ yields of energy corrected milk (ECM; 45.9 vs. 43.6 and $43.0 \mathrm{~kg} / \mathrm{d}$ ), true protein (1306 vs. 1221 and $1218 \mathrm{~g} / \mathrm{d}$ ), and fat (1632 vs. 1550 and 1543 $\mathrm{g} / \mathrm{d}$; Table 5). There was a trend $(P \leq 0.15)$ for cows fed RPMet+Lys to have higher yields of 3.5\% FCM than cows fed the basal diets or the basal diets supplemented with RPMet ( 45.9 vs. 43.8 and $43.1 \mathrm{~kg} / \mathrm{d}$ ).

There was no effect $(P>0.15)$ of dietary CP on yield of DMI, milk, ECM, FCM, and fat. Increases in yield of milk true protein in response to dietary $\mathrm{CP}$ content were dependent on week postpartum $(\mathrm{CP} \times$ week interaction, $P \leq 0.05$; Figure 1). Cows fed the $16 \% \mathrm{CP}$ diets produced more milk protein in the weeks immediately 
Table 5. Intake and milk production responses during the first $105 \mathrm{~d}$ of lactation of multiparous Holstein cows fed rumen-protected Met or rumen-protected Met plus Lys at 2 levels of dietary CP.

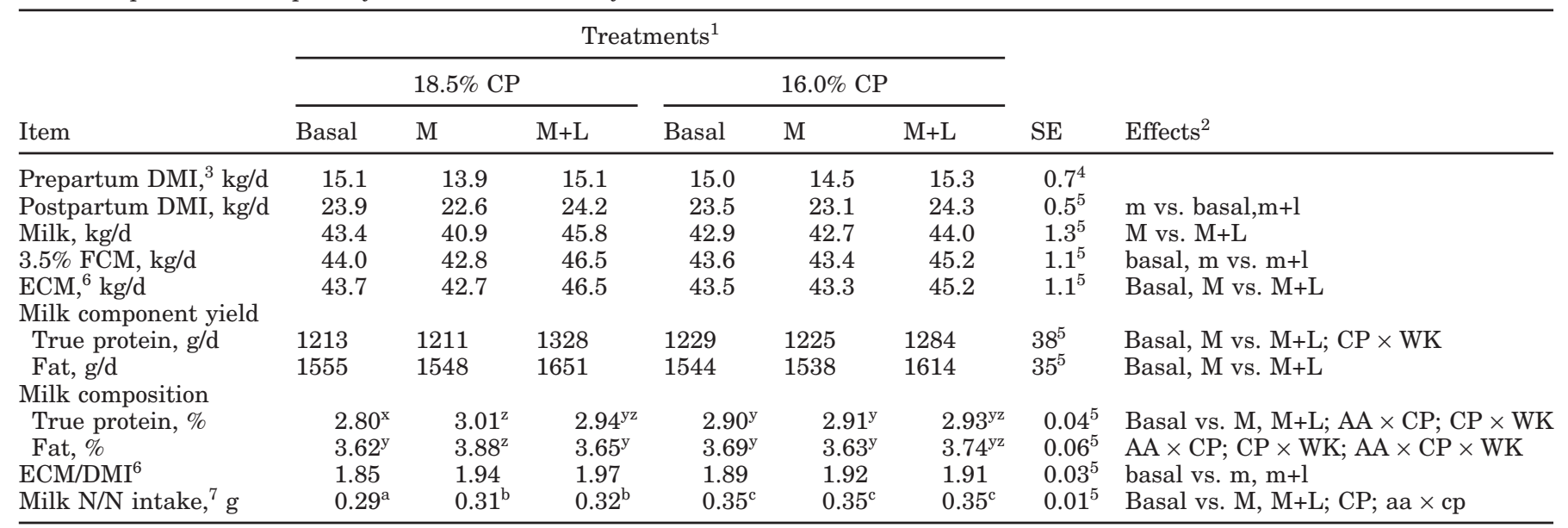

a,b,c Within a row, means with uncommon superscripts differ at $P \leq 0.15$.

$\mathrm{x}, \mathrm{y}, \mathrm{z}$ Within a row, means with uncommon superscripts differ at $P \leq 0.05$.

${ }^{1}$ Treatments were basal, $15 \mathrm{~g} / \mathrm{d}$ of a rumen-protected Met product which supplied $10.5 \mathrm{~g}$ of Met (M), and 6 g/d of rumen-protected Met product plus $40 \mathrm{~g} / \mathrm{d}$ of a rumen-protected Met plus Lys product which together supplied $10.2 \mathrm{~g}$ of Met and 16.0 g of Lys (M+L).

${ }^{2}$ Only treatment effects with $P \leq 0.15$ reported: $\mathrm{M}$ vs. $\mathrm{M}+\mathrm{L}, P \leq 0.05$; Basal, $\mathrm{M}$ vs. $\mathrm{M}+\mathrm{L}, P \leq 0.05$; basal, $\mathrm{m}$ vs. $\mathrm{m}+\mathrm{l}, P \leq 0.15$; basal vs $\mathrm{m}$, $\mathrm{m}+\mathrm{l}, P \leq 0.15 ; \mathrm{CP}=$ crude protein effect, $P \leq 0.05 ; \mathrm{AA} \times \mathrm{CP}=$ amino acid $\times$ crude protein interaction, $P \leq 0.05 ;$ aa $\times \mathrm{cp}=$ amino acid $\times$ crude protein interaction, $P \leq 0.15 ; \mathrm{CP} \times \mathrm{WK}=$ dietary crude protein by week interaction, $P \leq 0.05$; and $\mathrm{AA} \times \mathrm{CP} \times \mathrm{WK}=$ amino acid $\times$ dietary crude protein $\times$ week interaction, $P \leq 0.05$.

${ }^{3}$ Mean represents DMI of all cows for $7 \mathrm{~d}$ before parturition.

${ }^{4}$ Standard error of the least squares mean, $\mathrm{n}=26$.

${ }^{5}$ Standard error of the least squares mean, $\mathrm{n}=13$.

${ }^{6} \mathrm{ECM}=$ Energy-corrected milk; $3.5 \%$ fat, $3.2 \%$ protein.

${ }^{7}$ Milk $\mathrm{N}$ yield (kg) per kilogram of $\mathrm{N}$ intake.

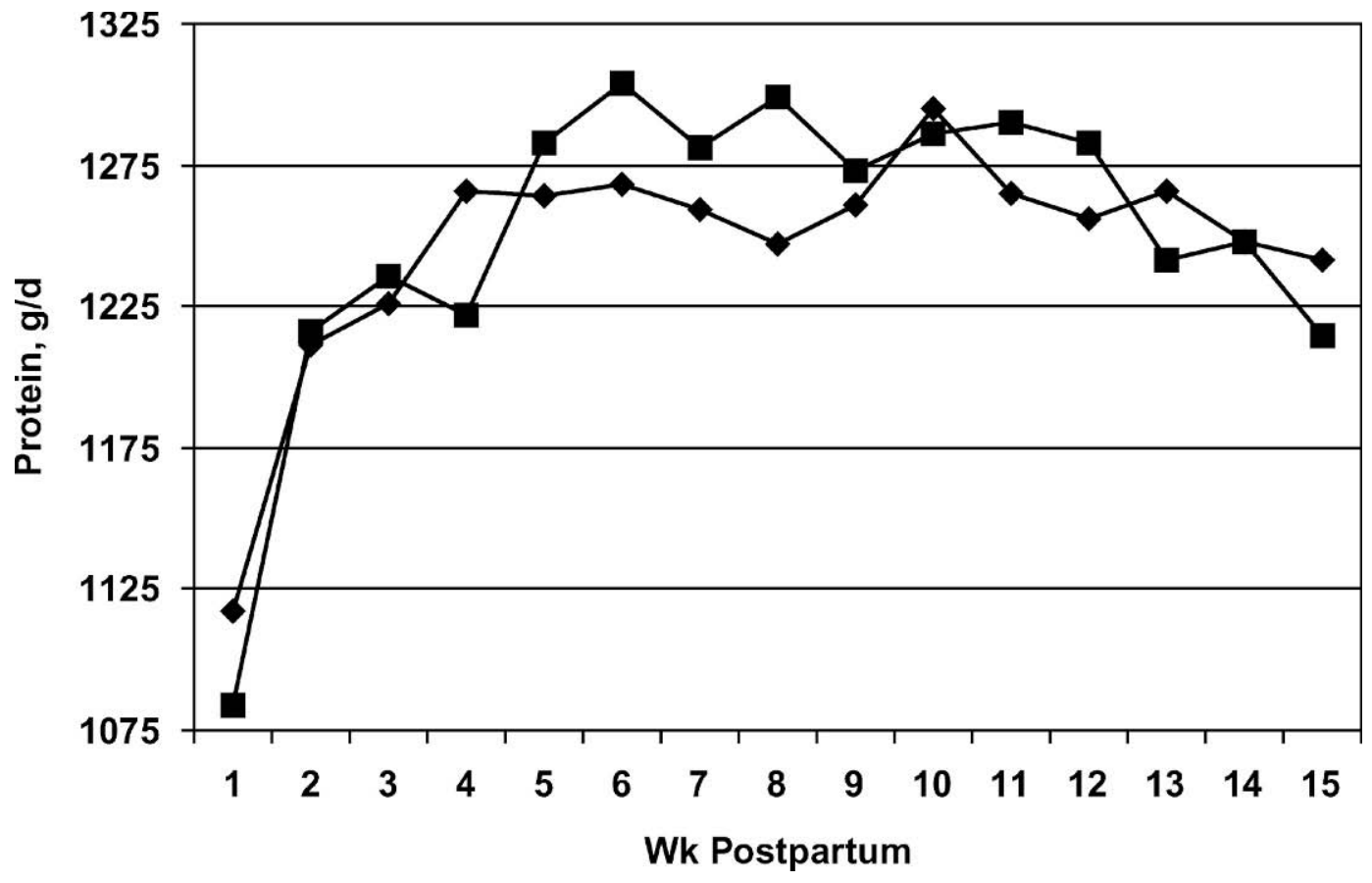

Figure 1. Response to dietary CP content across time: Production of milk true protein. 16.0\% CP diet ( $), 18.5 \% \mathrm{CP}$ diet $(\boldsymbol{\square})$. Week $\times$ dietary CP content, $(P \leq 0.05)$. Pooled SEM $=31.0$. 


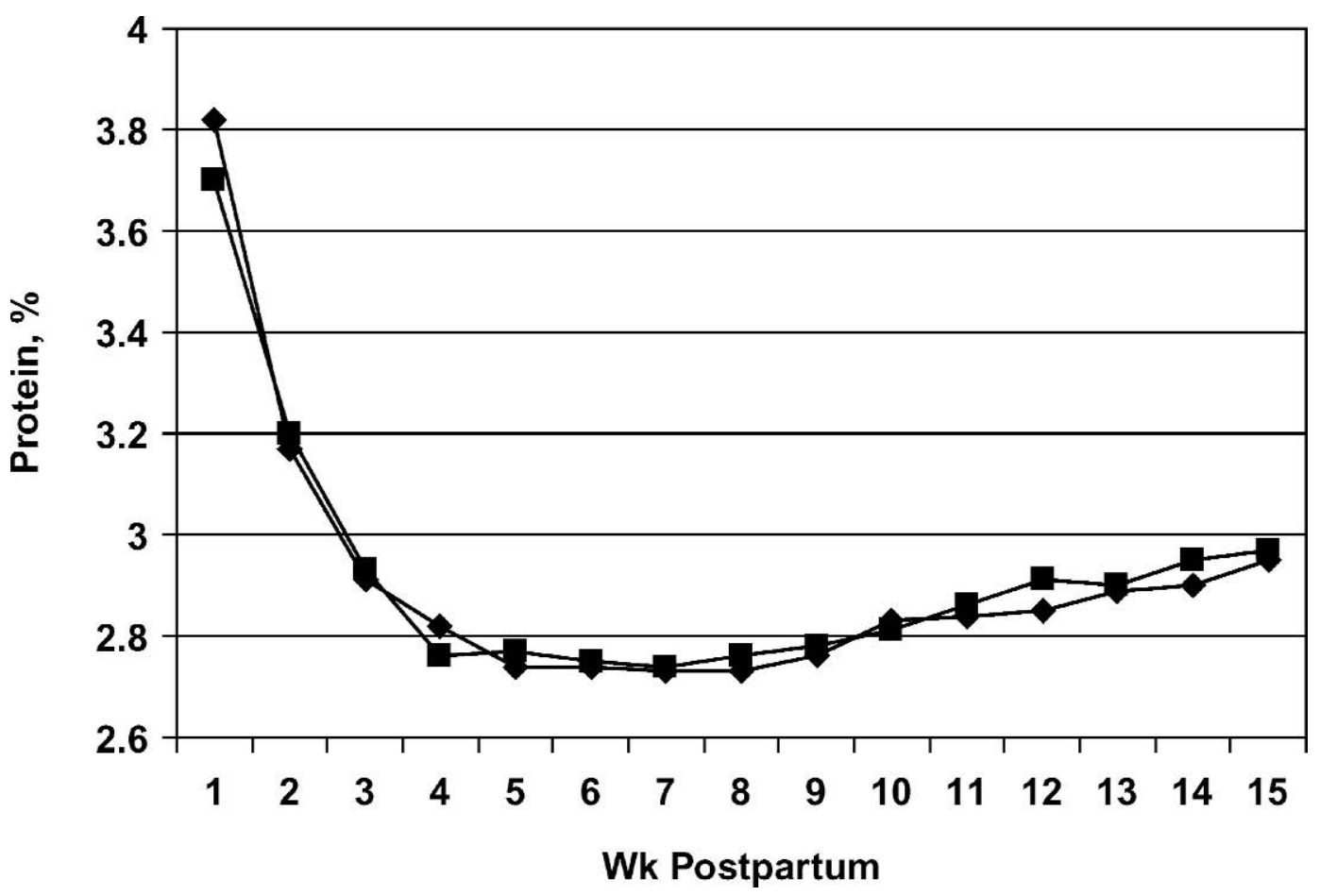

Figure 2. Response to dietary CP across time: Milk true protein content. $16.0 \% \mathrm{CP} \operatorname{diet}(\bullet), 18.5 \% \mathrm{CP} \operatorname{diet}(\boldsymbol{\square})$. Week $\times \operatorname{dietary} \mathrm{CP}$ content, $P \leq 0.05$. Pooled SEM $=0.04$.

after calving and as cows entered midlactation, whereas cows fed the $18.5 \% \mathrm{CP}$ diets produced more milk protein when cows were at peak production.

Supplementing the basal diets of lactating cows with RPMet or RPMet+Lys increased $(P \leq 0.05)$ percentage of true protein in milk (2.96 and 2.94 vs. 2.85) (Table $5)$. However, responses were not consistent across dietary $\mathrm{CP}$ level $(\mathrm{CP} \times \mathrm{AA}$ interaction, $P \leq 0.05)$. Supplementing 18.5B with RPMet and RPMet+Lys increased $(P \leq 0.05)$ milk true protein content 0.21 and 0.14 percentage units, whereas supplementing 16.0B with RPMet and RPMet+Lys had no effect. Similarly, RPAA supplementation of the basal diets had an inconsistent effect on milk fat content $(\mathrm{CP} \times \mathrm{AA}$ interaction, $P \leq$ $0.05)$. Adding RPMet to $18.5 \mathrm{~B}$ increased $(P \leq 0.05)$ milk fat content by 0.26 percentage units, but did not affect milk fat content when added to $16 \mathrm{~B}$.

The effect of dietary CP content on milk true protein and fat concentrations was dependent on stage of lactation $(\mathrm{CP} \times$ wk interaction, $P \leq 0.05)$. Compared with cows fed the $18.5 \% \mathrm{CP}$ diets, cows fed the $16.0 \% \mathrm{CP}$ diets produced milk with a higher protein content immediately following calving and a similar or lower protein content thereafter (Figure 2). Feeding the 16\% CP diets increased milk fat content in the immediate postpartum period and lowered milk fat content during wk
3 and 4 of lactation (Figure 3). Feeding the $18.5 \% \mathrm{CP}$ diets increased milk fat content as cows entered midlactation (Figure 3).

Effect of treatment on milk fat content was dependent on stage of lactation (AA $\times \mathrm{CP} \times$ wk interaction, $P \leq$ 0.05). Cows fed 18.5B produced milk with the lowest milk fat content immediately following parturition and at peak production. Cows fed $18.5 \mathrm{M}$ produced milk with the highest fat content immediately following calving and as cows approached peak production, whereas cows fed 16M produced milk with the lowest fat content as cows approached peak and midlactation (Figure 4).

Supplementing the basal diets with RPMet and RPMet+Lys tended to increase $(P \leq 0.15)$ the efficiency of conversion of DMI to ECM (1.93 and 1.94 vs. $1.87 \mathrm{~kg}$ of ECM/kg of DMI; Table 5). Similarly, efficiency of conversion of feed $\mathrm{N}$ to milk $\mathrm{N}$ increased $(P \leq 0.05)$ with RPMet and RPMet+Lys supplementation (0.33 and 0.34 vs. $0.32 \mathrm{~kg}$ of milk N/kg of feed N). However, responses tended to be inconsistent across dietary CP levels (AA $\times \mathrm{CP}$ interaction, $P \leq 0.15$ ), with efficiency of conversion of feed $\mathrm{N}$ to milk $\mathrm{N}$ tending to improve when RPMet and RPMet+Lys were added to the $18.5 \%$ CP diet, but not the $16 \%$ CP diet. Reducing dietary CP from 18.5 to $16.0 \%$ increased $(P \leq 0.05)$ efficiency of conversion of consumed $\mathrm{N}$ to milk $\mathrm{N}$ (0.31 to 0.35$)$. 


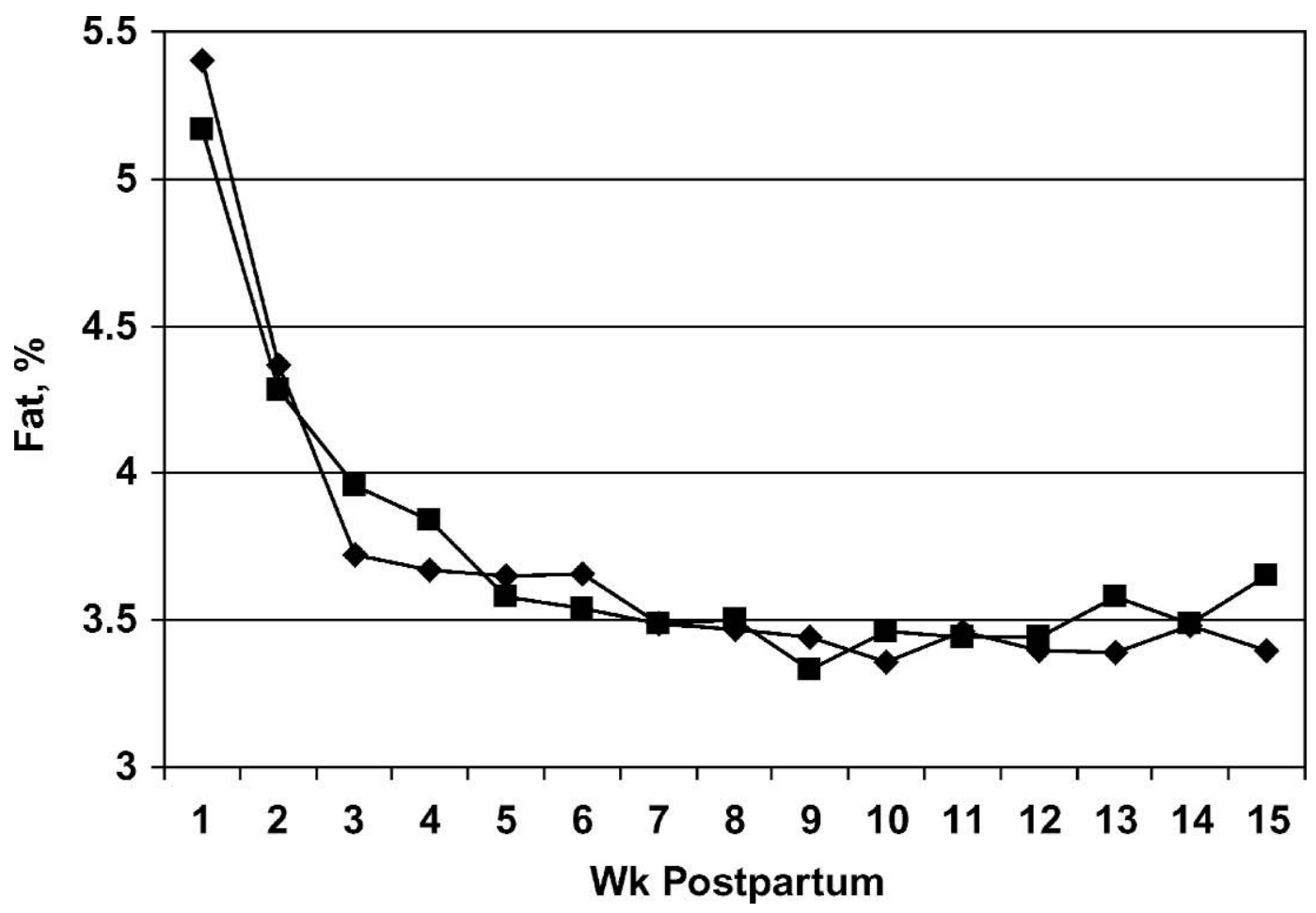

Figure 3. Response to dietary CP across time: Milk fat content. $16.0 \% \mathrm{CP} \operatorname{diet}(\diamond), 18.5 \% \mathrm{CP} \operatorname{diet}(\boldsymbol{\square})$. Week $\times \operatorname{dietary} \mathrm{CP}$ content, $P \leq$ 0.05. Pooled SEM $=0.09$.

There were no effects $(P>0.15)$ of treatment on BW or BW changes (Table 6). Cows receiving 18.5ML tended to have lower BCS $(P \leq 0.15)$ at wk 1 postpartum compared with cows receiving $18 \mathrm{~B}$, whereas $16 \mathrm{ML}$ cows tended to have higher $\mathrm{BCS}$ than $16 \mathrm{~B}$ cows $(\mathrm{AA} \times \mathrm{CP}$ interaction, $P \leq 0.15)$. There was no effect $(P>0.15)$ of treatment on body condition at wk 15 postpartum.

\section{Blood Metabolite Concentrations}

There were no effects of treatment $(P>0.15)$ on postpartum plasma NEFA and BHBA concentrations (Table 7). Cows fed RPMet+Lys tended to have lower plasma glucose concentrations $(P \leq 0.15)$ than cows fed only the basal diet. Feeding RPMet reduced serum urea concentrations $(P \leq 0.05)$ compared with feeding no RPAA or feeding RPMet+Lys. Cows fed the $16.0 \%$ CP diets had lower serum urea concentrations $(P \leq 0.05)$ than cows fed the $18.5 \% \mathrm{CP}$ diets (Table 7 ).

The effect of RPAA supplementation on plasma glucose concentrations was dependent upon week postpartum (AA $\times$ week interaction, $P \leq 0.05$; Figure 5 ). Between wk 1 and 4 postpartum, plasma glucose concentrations of cows receiving RPMet+Lys declined at a more rapid rate than cows receiving either the basal diet or RPMet. However, between wk 4 and 7 postpartum, plasma glucose concentrations of RPMet+Lys sup- plemented cows increased, whereas plasma glucose concentrations of cows receiving no RPAA or RPMet remained essentially unchanged.

The effect of dietary CP and RPAA supplementation on plasma glucose concentration was not consistent across time (AA $\times \mathrm{CP} \times$ week interaction, $P \leq 0.05$ ). Immediately following parturition, glucose concentrations decreased for cows receiving 16M, 16ML, 18.5B, and $18.5 \mathrm{ML}$, and increased for cows receiving $18.5 \mathrm{M}$ (Figure 6). As cows approached peak production, plasma glucose concentrations decreased for cows receiving the $16 \mathrm{M}, 18.5 \mathrm{~B}$, and $18.5 \mathrm{M}$ treatments and increased for cows receiving $16 \mathrm{ML}$ and $18.5 \mathrm{ML}$. The large drop in glucose concentrations following parturition for cows fed RPMet+Lys may be attributed at least in part to the higher yield of ECM (Table 7).

Incidences of health disorders were minimal. One cow fed the 18.5ML diet was treated for displaced abomasum. Nine cows were treated for off-feed problems related to subclinical or clinical ketosis; 1 fed 16B, 2 fed $16 \mathrm{M}, 1$ fed 16ML, 2 fed 18.5B, 2 fed 18.5M, and 1 fed 18.5ML.

\section{DISCUSSION}

\section{Lactation Responses to RPMet and RPMet+Lys}

The first 2 objectives of this study were to determine milk production responses of early-lactation dairy cows 


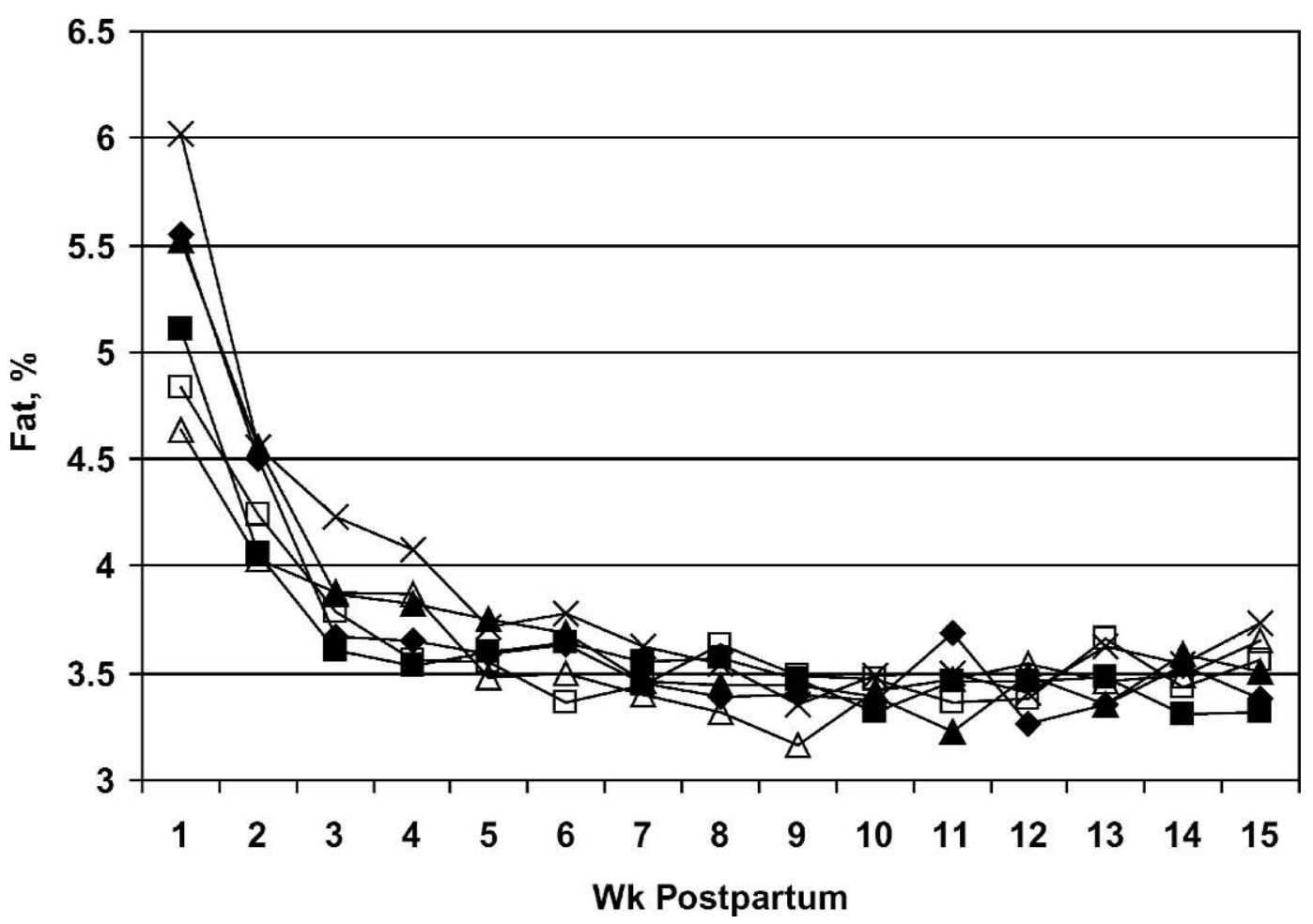

Figure 4. Response to dietary $\mathrm{CP}$ and amino acid supplementation across time: Milk fat content. 16\% CP diet, no rumen-stable AA supplementation ( ), 16\% CP diet plus rumen-protected Met product that supplied $10.5 \mathrm{~g}$ of Met (⿴), $16 \%$ CP diet plus rumen-protected Met plus Lys product that supplied $10.2 \mathrm{~g}$ of Met and $16.0 \mathrm{~g}$ of Lys ( $\mathbf{\Delta}), 18.5 \% \mathrm{CP}$ diet, no rumen-stable AA supplementation $(\triangle), 18.5 \%$ CP diet plus rumen-protected Met product that supplied $10.5 \mathrm{~g}$ Met $(\times), 18.5 \% \mathrm{CP}$ diet plus rumen-protected Met plus Lys product that supplied $10.2 \mathrm{~g}$ of Met and $16.0 \mathrm{~g}$ of Lys $(\square)$. Week $\times \mathrm{AA} \times$ dietary $\mathrm{CP}$ supplementation effect, $P \leq 0.05$. Pooled SEM $=0.16$.

to RPMet and RPMet+Lys supplementation when supplementation commenced in late gestation and cows were fed corn-based diets containing high-Lys protein supplements. Compared with cows receiving no RPAA, cows receiving RPMet+Lys produced more ECM (45.9 vs. $43.6 \mathrm{~kg} / \mathrm{d})$, true protein (1306 vs. $1221 \mathrm{~g} / \mathrm{d})$, and fat

Table 6. Body weight and body condition score responses during the first $105 \mathrm{~d}$ of lactation of multiparous Holstein cows fed rumen-protected Met or rumen-protected Met plus Lys at 2 levels of dietary CP.

\begin{tabular}{|c|c|c|c|c|c|c|c|c|}
\hline \multirow[b]{3}{*}{ Item } & \multicolumn{6}{|c|}{ Treatments $^{1}$} & \multirow[b]{3}{*}{$\mathrm{SE}^{2}$} & \multirow[b]{3}{*}{ Effects $^{3}$} \\
\hline & \multicolumn{3}{|c|}{$18.5 \% \mathrm{CP}$} & \multicolumn{3}{|c|}{$16.0 \% \mathrm{CP}$} & & \\
\hline & Basal & $\mathrm{M}$ & $\mathrm{M}+\mathrm{L}$ & Basal & $\mathrm{M}$ & $\mathrm{M}+\mathrm{L}$ & & \\
\hline \multicolumn{9}{|l|}{$\mathrm{BW}, \mathrm{kg}$} \\
\hline Wk 1 & 633 & 636 & 642 & 623 & 611 & 651 & 16 & \\
\hline Wk 15 & 618 & 619 & 629 & 612 & 601 & 626 & 17 & \\
\hline Change (wk $15-$ wk 1 ) & -15 & -16 & -13 & -11 & -10 & -25 & 9 & \\
\hline \multicolumn{9}{|l|}{$\mathrm{BCS}$} \\
\hline Wk 1 & $3.6^{\mathrm{c}}$ & $3.5^{\mathrm{bc}}$ & $3.4^{\mathrm{a}}$ & $3.3^{\mathrm{a}}$ & $3.3^{\mathrm{a}}$ & $3.6^{\mathrm{c}}$ & 0.1 & $\mathrm{aa} \times \mathrm{cp}$ \\
\hline Wk 15 & 2.8 & 2.6 & 2.5 & 2.6 & 2.7 & 2.8 & 0.2 & \\
\hline Change (wk $15-$ wk 1 ) & -0.7 & -0.9 & -0.9 & -0.6 & -0.6 & -0.7 & 0.2 & \\
\hline
\end{tabular}

a,b,c Within a row, means with uncommon superscripts differ at $P \leq 0.15$.

${ }^{1}$ Treatments were basal, $15 \mathrm{~g} / \mathrm{d}$ of a rumen-protected Met product which supplied $10.5 \mathrm{~g}$ of Met (M), and $6 \mathrm{~g} / \mathrm{d}$ of rumen-protected Met product plus $40 \mathrm{~g} / \mathrm{d}$ of a rumen-protected Met plus Lys product which together supplied $10.2 \mathrm{~g}$ of Met and $16.0 \mathrm{~g}$ of Lys $(\mathrm{M}+\mathrm{L})$.

${ }^{2}$ Standard error of the least squares mean; $\mathrm{n}=11$ for BW; $\mathrm{n}=13$ for BCS.

${ }^{3}$ Only treatment effects with $P \leq 0.15$ reported; aa $\times \mathrm{cp}=$ amino acid by crude protein interaction, $P \leq$ 0.15 . 
Table 7. Blood metabolite concentrations of early-lactation multiparous Holstein cows fed rumen-protected Met or rumen-protected Met plus Lys at 2 levels of dietary CP.

\begin{tabular}{|c|c|c|c|c|c|c|c|c|}
\hline \multirow[b]{2}{*}{ Item } & \multicolumn{6}{|c|}{ Treatments $^{1}$} & \multirow[b]{2}{*}{$\mathrm{SE}^{2}$} & \multirow[b]{2}{*}{ Effects $^{3}$} \\
\hline & Basal & M & $\mathrm{M}+\mathrm{L}$ & Basal & M & $\mathrm{M}+\mathrm{L}$ & & \\
\hline \multicolumn{9}{|l|}{ Plasma metabolites } \\
\hline Glucose, $\mathrm{mg} / \mathrm{dL}$ & 79.7 & 79.4 & 74.7 & 81.0 & 78.3 & 73.8 & 3.1 & basal vs. $\mathrm{m}+\mathrm{l}$; $\mathrm{AA} \times \mathrm{WK} ; \mathrm{AA} \times \mathrm{CP} \times \mathrm{WK}$ \\
\hline $\mathrm{NEFA}, \mu \mathrm{mol} / \mathrm{L}$ & 377 & 447 & 431 & 399 & 374 & 461 & 37 & \\
\hline $\mathrm{BHBA}, \mathrm{mg} / \mathrm{dL}$ & 5.14 & 4.83 & 5.75 & 4.48 & 4.27 & 4.68 & 0.67 & \\
\hline
\end{tabular}

${ }^{1}$ Treatments were basal, $15 \mathrm{~g} / \mathrm{d}$ of a rumen-protected Met product which supplied $10.5 \mathrm{~g}$ of Met (M), and $6 \mathrm{~g} / \mathrm{d}$ of rumen-protected Met product plus $40 \mathrm{~g} / \mathrm{d}$ of a rumen-protected Met plus Lys product which together supplied $10.2 \mathrm{~g}$ of Met and 16.0 g of Lys (M+L).

${ }^{2}$ Standard error of the least squares mean, $\mathrm{n}=13$.

${ }^{3}$ Only treatment effects with $P \leq 0.15$ reported: basal vs. $\mathrm{m}+\mathrm{l}, P \leq 0.15$; Basal, $\mathrm{M}+\mathrm{L}$ vs. $\mathrm{M}, P \leq 0.05$; $\mathrm{CP}=$ crude protein effect, $P \leq 0.05$; $\mathrm{AA} \times \mathrm{WK}=$ amino acid by week interaction, $P \leq 0.05 ; \mathrm{AA} \times \mathrm{CP} \times \mathrm{WK}=$ amino acid by dietary crude protein by week interaction, $P \leq 0.05$.

(1632 vs. $1550 \mathrm{~g} / \mathrm{d}$, Table 5), and tended to produce more $3.5 \%$ FCM ( 45.9 vs. $43.8 \mathrm{~kg} / \mathrm{d}$ ). These production responses to RPMet+Lys were larger than reported previously by others (Armentano et al., 1993; Rulquin and Vérité, 1993) and support the hypothesis that the greatest responses to improved Lys and Met nutrition occur during the earliest stages of lactation when the need for absorbed AA, relative to absorbed energy, is the highest.
The larger than expected response in milk yield to the increased intestinal supplies of Lys and Met in this study may be attributed to the fact that the cows received supplemental AA before calving. In 3 other trials in which RPMet or RPMet+Lys were added to lactating dairy diets beginning before calving and continuing through early lactation, milk yield was increased by an average of $1.2 \mathrm{~kg} / \mathrm{d}$ (Overton et al., 1996; Carson et al., 1998; Xu et al., 1998). In comparison, initiating RPMet,

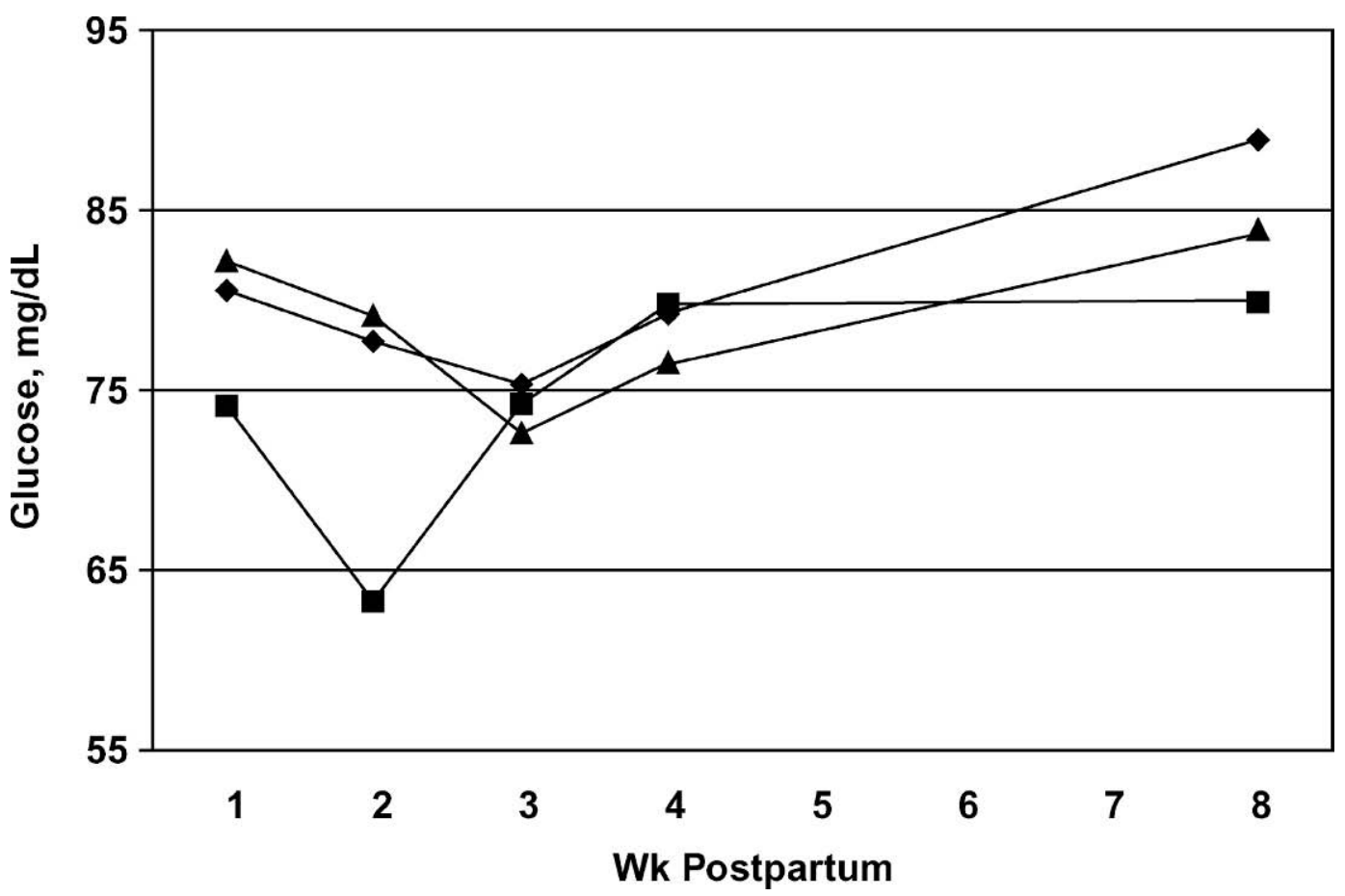

Figure 5. Response to amino acid supplementation across time: Plasma glucose concentration. Basal diet, no rumen-stable AA supplementation $(\diamond)$, basal diet plus rumen-protected Met product that supplied $10.5 \mathrm{~g}$ Met $(\boldsymbol{\Lambda})$ and basal diet plus rumen-protected Met plus Lys product that supplied $10.2 \mathrm{~g}$ of Met and $16.0 \mathrm{~g}$ of Lys $(\mathbf{\square})$. Week $\times$ AA supplementation effect, $P \leq 0.05$. Pooled SEM $=3.4$. 


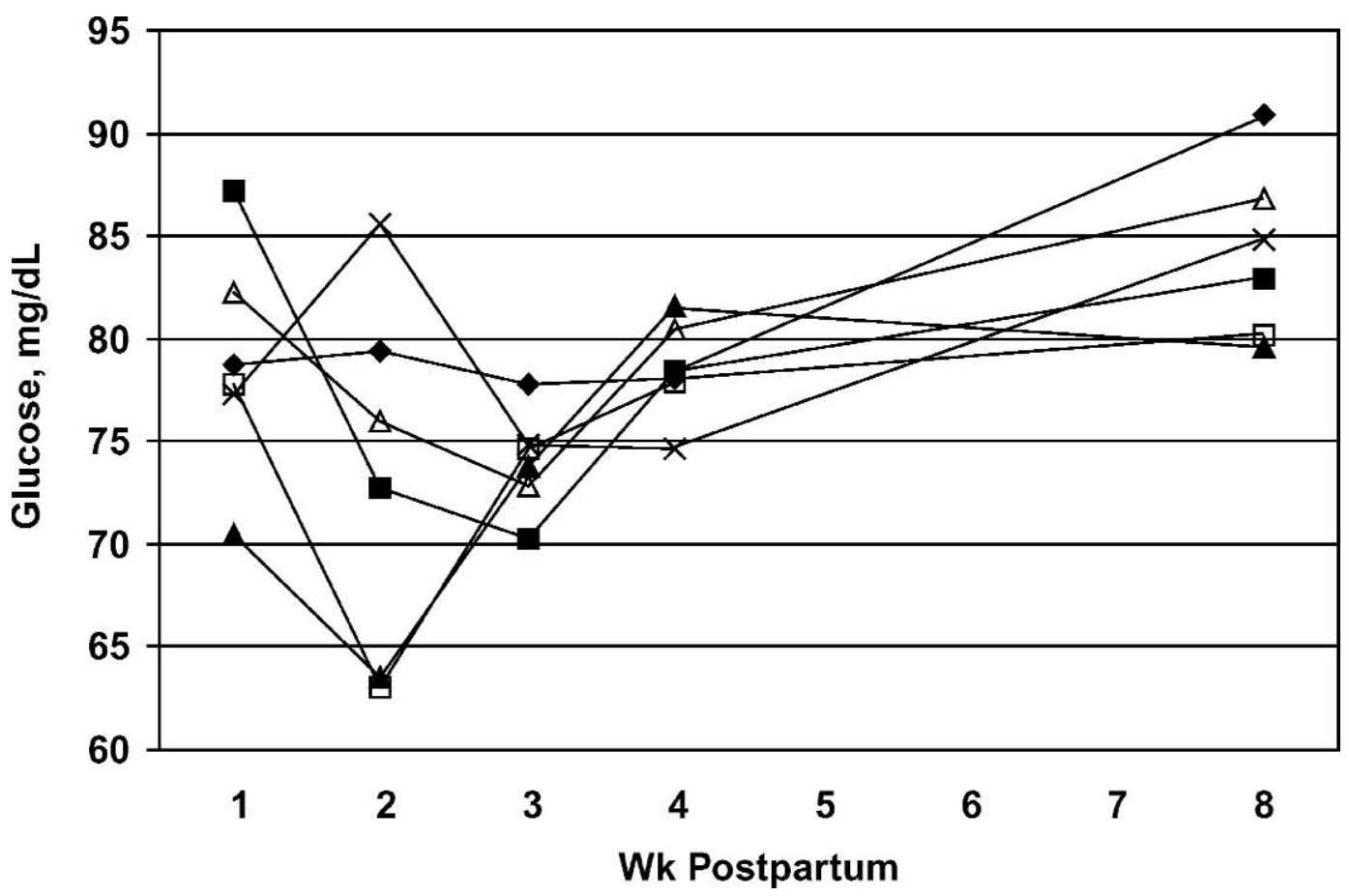

Figure 6. Response to dietary $\mathrm{CP}$ and amino acid supplementation across time: Plasma glucose concentration. $16 \% \mathrm{CP}$ diet, no rumen-

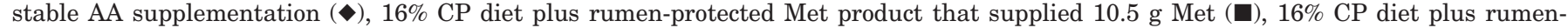
protected Met plus Lys product that supplied $10.2 \mathrm{~g}$ of Met and $16.0 \mathrm{~g}$ of Lys $(\mathbf{\Delta}), 18.5 \% \mathrm{CP}$ diet, no rumen-stable AA supplementation $(\triangle)$, $18.5 \%$ CP diet plus rumen-protected Met product that supplied $10.5 \mathrm{~g}$ Met $(\times), 18.5 \% \mathrm{CP}$ diet plus rumen-protected Met plus Lys product that supplied $10.2 \mathrm{~g}$ of Met and $16.0 \mathrm{~g}$ of Lys $(\square)$. Week $\times$ AA $\times$ dietary CP supplementation effect, $P \leq 0.05$. Pooled SEM $=4.0$.

RPLys, or RPMet+Lys supplementation after parturition (wk 1 to 20 postpartum) increased milk yield an average of only $0.1 \mathrm{~kg} / \mathrm{d}$ (Armentano et al., 1993; Wu et al., 1997; Bertrand et al., 1998; Robinson et al., 1998; Samuelson et al., 2001; Moore et al., 2003; Noftsger and St. Pierre, 2003). However, increases in milk protein yield in response to RPAA supplementation appeared to be less affected by the stage of lactation in which supplementation was initiated. In the above experiments, starting supplementation before calving increased milk protein yield an average of $82 \mathrm{~g} / \mathrm{d}$ (an increase of 7.1\%), whereas initiating AA supplementation after calving increased milk protein yield an average of $35 \mathrm{~g} / \mathrm{d}$ (an increase of $3.1 \%$ ).

This experiment revealed no significant interactions of dietary $\mathrm{CP}$ and $\mathrm{AA}$ supplementation for milk and milk component yields. However, milk and milk component yield responses to RPMet+Lys were numerically greater with the $18.5 \% \mathrm{CP}$ diet than with the $16.0 \%$ $\mathrm{CP}$ diet (Table 5). Greater responses to RPLys+Met supplementation of $18.5 \mathrm{~B}$ could have occurred if feeding this diet resulted in Lys, Met, or both being more deficient than feeding 16.0B. However, this did not appear to be the case. The 2 basal diets were evaluated with the NRC (2001) model and predicted flows of MP-Lys and MP-Met were 172 and $44 \mathrm{~g} / \mathrm{d}$ for $18.5 \mathrm{~B}$ and 157 and $42 \mathrm{~g} / \mathrm{d}$ for $16.0 \mathrm{~B}$ when DMI was held constant at $23.6 \mathrm{~kg} / \mathrm{d}$ (Table 4). The higher predicted flows of MPLys and MP-Met for 18.5B resulted primarily because of higher predicted flows of MP (2745 vs. $2582 \mathrm{~g} / \mathrm{d}$ ). The predicted concentrations of Lys and Met in MP for the 2 basal diets were similar (6.3 and $1.6 \%$ for $18.5 \mathrm{~B} ; 6.1$ and $1.6 \%$ for 16.0B) (Table 4). These results are supported by observations in a companion experiment where the 2 basal diets were fed to early-lactation, primiparous Holstein cows that were fitted with ruminal and duodenal cannulas (Putnam et al., 1997). Measured concentrations of Lys and Met in total AA of duodenal digesta were 6.8 and $2.0 \%$ for both diets. Measured flows of total AA for 18.5B and 16.0B were 3420 and $3042 \mathrm{~g} / \mathrm{d}$, respectively. Intakes of $\mathrm{DM}$ for $18.5 \mathrm{~B}$ and 16.0B were 18.3 and $18.1 \mathrm{~kg} / \mathrm{d}$, respectively.

The increase in milk protein yield with RPMet+Lys supplementation in this study is consistent with other results (Donkin et al., 1989; Chapoutot et al., 1992; Robinson et al., 1992; Armentano et al., 1993; Robinson et al., 1993). However, in contrast to the previous observations, the increased yield of milk protein in the current experiment occurred mainly because of an increase 
in milk production, rather than an increase in milk protein content.

Somewhat surprising was the fact that feeding RPMet alone did not increase yield of milk protein and increased content of milk protein only when added to 18.5B (Table 5). It is concluded in NRC (2001) that the required concentrations of Lys and Met in MP for maximum content and yield of milk protein are 7.1 to 7.2 and $2.4 \%$, respectively, when the NRC (2001) model is used to predict concentrations of AA in MP. If these required concentrations are correct, then the optimum Lys:Met ratio in MP is 3.0:1. However, the evaluation of 18.5B and 16.0B with NRC (2001) yielded Lys:Met ratios in MP of 3.9:1 (6.3:1.6) and 3.8:1 (6.1:1.6), respectively (Table 4). In the companion study, Putnam et al. (1997) observed Lys:Met ratios in duodenal digesta of 3.5:1 for both of the basal diets. Predicted duodenal supplies of Lys and Met using a factorial model (CPMDairy, version 3.0; New Bolton Center, University of Pennsylvania, Kennett Square, PA) resulted in Lys:Met ratios of $3.4: 1$ and $3.3: 1$, respectively, for $18.5 \mathrm{~B}$ and $16.0 \mathrm{~B}$. In all cases, it is concluded that Met was more limiting than Lys and that the cows should have responded to RPMet supplementation.

One factor that may have contributed to cows not responding with increased yield of milk protein to RPMet supplementation is that the digestibility of Lys in the RUP fraction of blood meal may have been less than the measured digestibility coefficient of $60.7 \%$ for RUP. Of concern is that the blood meal was exposed to excessive heat during processing. This possibility is supported by the observations that the measured RUP digestibility (60.7\% of CP) and Lys content $(7.70 \%$ of $\mathrm{CP}$ ) of the ring-dried blood meal (Table 3) are both less than the NRC (2001) default values of 80 and $8.98 \%$, respectively. It is well documented that Lys is the most vulnerable of the essential amino acids to heat damage (Schwab, 1995). For example, increasing the amount of heat applied to cottonseed meal (Broderick and Craig, 1980; Craig and Broderick, 1981), soybean meal (Parsons et al., 1992), and whole soybeans (Faldet et al., 1992) has been shown to decrease Lys concentration and the availability of the remaining Lys. There was no attempt in this experiment to measure Lys digestibility in the blood meal. However, it is of interest to note that even if Lys digestibility in the RUP fraction of the blood meal was decreased to $30 \%$, calculated flows of MP-Lys would be decreased by $6 \mathrm{~g}$ for $18.5 \mathrm{~B}$ and 5 $\mathrm{g}$ for $16.0 \mathrm{~B}$, lowering the Lys:Met ratios in MP from $3.9: 1$ and $3.7: 1$ for the 2 basal diets to $3.8: 1$ and $3.6: 1$, respectively.

\section{CP-Sparing Effect of RPAA}

The third objective of this study was to assess the dietary CP-sparing effect of RPMet and RPMet+Lys.
This was difficult to assess as CP only affected efficiency of conversion of dietary $\mathrm{N}$ to milk $\mathrm{N}$ and the only significant $\mathrm{CP} \times \mathrm{AA}$ effects were observed for milk fat and true protein content. However, cows receiving $16 \mathrm{ML}$ numerically consumed more DM (24.3 vs. $23.9 \mathrm{~kg} / \mathrm{d})$, produced more ECM ( $45.2 \mathrm{vs} .43 .7 \mathrm{~kg} / \mathrm{d}$ ), and converted dietary $\mathrm{N}$ to milk $\mathrm{N}$ with a higher gross efficiency (35 vs. 29\%) than cows receiving 18.5B (Table 5). These results suggest that $16 \mathrm{ML}$ was similar, if not superior, in nutritive value to $18.5 \mathrm{~B}$.

Accurate assessment of the CP-sparing effects of RPMet and RPMet+Lys requires a number of diets with varying levels of $\mathrm{CP}$, and more specifically, different levels of RUP rather than RDP. Thus, the treatments in this study did not lend themselves to effectively determining the CP-sparing effect of RPAA, as response to RPMet and RPMet+Lys was examined at only 2 dietary CP levels, and CP levels were increased from 16 to $18.5 \% \mathrm{CP}$ by increasing the $\mathrm{RDP}$ fraction rather than the RUP fraction.

\section{Effect of RPAA on Blood Energy Metabolites}

There was no effect of RPAA supplementation on clinical ketosis and other postcalving metabolic disorders. This is consistent with the lack of an observed effect of RPAA supplementation on postpartum plasma NEFA and BHBA. Effect of RPAA supplementation on plasma glucose was dependent on week postpartum, with cows supplemented with RPMet+Lys having lower plasma glucose concentrations during wk 1 and 2 postpartum than cows fed the other diets. The lower plasma glucose concentrations may be reflective of the fact that the cows supplemented with RPMet+Lys produced more ECM; across the 2-wk period, the cows produced $2.8 \mathrm{~kg} / \mathrm{d}$ more ECM than the other cows (42.2 vs. 39.4 $\mathrm{kg}$ ) while consuming only $0.9 \mathrm{~kg} / \mathrm{d}$ more DM (17.7 vs. $16.8 \mathrm{~kg})$. For the last $13 \mathrm{wk}$ of the 15 -wk treatment period, the cows fed RPMet+Lys produced $2.5 \mathrm{~kg} / \mathrm{d}$ more ECM than the other cows ( 46.4 vs. $43.9 \mathrm{~kg})$ and consumed $1.0 \mathrm{~kg} / \mathrm{d}$ more DM (25.3 vs. $24.3 \mathrm{~kg})$. In previous research, plasma NEFA, glucose, and BHBA were not affected when lactating dairy cows were fed RPMet+Lys (Chow et al., 1990; Chapoutot et al., 1992; Xu et al., 1998).

In contrast, postruminal infusion of a basal amount of Lys and incremental amounts of Met resulted in a linear increase in plasma BHBA of cows entering the second $100 \mathrm{~d}$ of lactation (Socha, 1994), but had no effect on plasma BHBA of cows assigned to the treatments before 50 DIM (Pisulewski et al., 1996; Socha, 1994) or after 150 DIM (Socha, 1994). In these same infusion studies, increasing the intestinal supply of Met linearly reduced plasma NEFA concentrations when the cows 
were assigned to the studies before 50 DIM (Pisulewski et al., 1996; Socha, 1994) but not when they began receiving treatments as they approached 100 DIM or after 150 DIM (Socha, 1994). One potential reason why blood concentrations of energy metabolites such as NEFA, BHBA, and glucose are not affected by improved Lys and Met nutrition in production studies (Chow et al., 1990; Chapoutot et al., 1992; Xu et al., 1998) is that the effect may be transitory. In the production studies, the experimental periods were $21 \mathrm{~d}$ or longer, with blood samples usually being collected several weeks after initiation of treatments. This is in contrast to the infusion experiments where the length of experimental periods was 10 to $14 \mathrm{~d}$ and all blood samples were taken less than 2 wk after initiation of treatments (Socha, 1994; Pisulewski et al., 1996).

\section{CONCLUSIONS}

Supplementing the basal diets of early lactation cows with RPMet+Lys increased yield of ECM, milk true protein, and milk fat and tended to decrease concentrations of plasma glucose. It was difficult to assess the CP-sparing effect of RPMet+Lys due to the lack of a dietary $\mathrm{CP}$ or $\mathrm{CP} \times \mathrm{AA}$ effect on production of milk and milk components. However, cows receiving $16 \mathrm{ML}$ produced numerically more milk, FCM, ECM, protein, and fat than cows receiving 18.5B. Dairy cows in early lactation are sensitive to changes in intestinal AA balance, and their lactation performance may be enhanced considerably by optimizing Lys and Met nutrition. The lack of a response to RPMet illustrates the importance of characterizing the protein fractions of protein sources.

\section{ACKNOWLEDGMENTS}

The authors extend appreciation to D. M. Socha, J. M. Whitehouse, R. A. Comeau, G. C. Lee, D. H. McDonald, J. W. Weeks, and student employees for care and feeding of cows; to R. P. Blakemore, G. B. Carey, J. B. Holter, K. L. Koch, and V. A. Wasserstrom for manuscript review; to W. E. Urban, Jr. and N. R. St-Pierre for assistance in statistical analysis; to H. H. Hayes for technical assistance; to M. J. Cecava for assistance in AA analysis; to M. D. Stern for analysis of the heattreated protein supplements; and to Alifet USA, and West Central Co-op for product donation. Finally, we would like to thank Adisseo for their financial support. Without their financial support, this study would not have been possible.

\section{REFERENCES}

Armentano, L. E., S. M. Swain, and G. A. Ducharme. 1993. Lactation responses to ruminally protected methionine and lysine at two amounts of ruminally available nitrogen. J. Dairy Sci. 76:2963-2969.

Barham, D., and P. Trinder. 1972. An improved colour reagent for the determination of blood glucose by the oxidase system. Analyst 97:142-145.

Bertrand, J. A., F. E. Pardue, and T. C. Jenkins. 1998. Effect of ruminally protected amino acids on milk yield and composition of Jersey cows fed whole cottonseed. J. Dairy Sci. 81:2215-2220.

Broderick, G. A., and W. M. Craig. 1980. Effect of heat treatment on ruminal degradation and escape, and intestinal digestibility of cottonseed meal protein. J. Nutr. 110:2381-2389.

Calsamiglia, S., and M. D. Stern. 1995. A three-step in vitro procedure for estimating intestinal digestion of protein in ruminants. J. Anim. Sci. 73:1459-1465.

Carson, V. M., N. L. Whitehouse, K. Kolinsky, B. D. Garthwaite, M. S. Piepenbrink, and C. G. Schwab. 1998. Interactions of prepartum and postpartum feeding of rumen inert amino acids on lactational performance of Holstein cows. J. Dairy Sci. 81(Suppl. 1):295. (Abstr.)

Chapoutot, P., P. Schmidely, D. Sauvant, J. C. Robert, and B. Sloan. 1992. Influence of a ruminally protected blend of methionine and lysine (ML) on the dairy cow nutrition and production. J. Dairy Sci. 75(Suppl. 1):199. (Abstr.)

Chow, J. M., E. J. DePeters, and R. L. Baldwin. 1990. Effect of rumenprotected methionine and lysine on casein in milk when diets high in fat or concentrate are fed. J. Dairy Sci. 73:1051-1061.

Craig, W. M., and G. A. Broderick. 1981. Effect of treatment on true digestibility in the rat, in vitro proteolysis and available lysine content of cottonseed meal protein. J. Anim. Sci. 52:292-301.

Crocker, C. L. 1967. Rapid determination of urea nitrogen in serum or plasma without deproteinization. Am. J. Med. Technol. 33:361-365.

Donkin, S. S., G. A. Varga, T. F. Sweeney, and L. D. Muller. 1989. Rumen-protected methionine and lysine: Effects on animal performance, milk protein yield, and physiological measures. J. Dairy Sci. 72:1484-1491.

Faldet, M. A., L. D. Satter, and G. A. Broderick. 1992. Determining optimal heat treatment of soybeans by measuring available lysine chemically and biologically with rats to maximize protein utilization by ruminants. J. Nutr. 122:151-160.

Gibbard, S., and P. J. Watkins. 1968. A micromethod for the enzymatic determination of $\mathrm{D}-\beta$-hydroxybutyrate and acetoacetate. Clin. Chim. Acta 19:511-521.

Johnson, M. M., and J. P. Peters. 1993. An improved method to quantify nonesterified fatty acids in bovine plasma. J. Anim. Sci. 71:753-756.

Le Henaff, L., H. Rulquin, and R. Vérité. 1990. Lactational responses to postruminal infusions of amino acids in dairy cows fed with maize silage, hay or grass silage. Reprod. Nutr. Dev. (Suppl. 2):237.

Moore, C. E., B. K. Sloan, D. A. Henderson, and L. H. Baumgard. 2003. Technique to measure the bioavailability of rumen protected methionine supplements. J. Dairy Sci. 86(Suppl. 1):271. (Abstr.)

National Research Council. 2001. Nutrient Requirements of Dairy Cattle. 7th rev. ed. Natl. Acad. Sci., Washington, DC.

Noftsger, S., and N. R. St-Pierre. 2003. Supplementation of methionine and selection of highly digestible rumen undegradable protein to improve nitrogen efficiency for milk production. J. Dairy Sci. 86:958-969.

Overton, T. R., D. W. LaCount, T. M. Cicela, and J. H. Clark. 1996. Evaluation of a ruminally protected methionine product for lactating dairy cows. J. Dairy Sci. 79:631-638.

Parsons, C. M., K. Hashimoto, K.-J. Wedekind, Y. Han, and D. H. Baker. 1992. Effect of overprocessing on availability of amino acids and energy in soybean meal. Poult. Sci. 71:133-140.

Pisulewski, P. M., H. Rulquin, J. L. Peyraud, and R. Vérité. 1996. Lactational and systemic responses to postruminal infusions of increasing levels of methionine in dairy cows. J. Dairy Sci. 79:1781-1791.

Polan, C. E., K. A. Cummins, C. J. Sniffen, T. V. Muscato, J. L. Vicini, B. A. Crooker, J. H. Clark, D. G. Johnson, D. E. Otterby, B. 
Guillaume, L. D. Muller, G. A. Varga, R. A. Murray, and S. B. Peirce-Sandner. 1991. Responses of dairy cows to supplemental rumen-protected forms of methionine and lysine. J. Dairy Sci. 74:2997-3013.

Putnam, D. E., C. G. Schwab, M. T. Socha, N. L. Whitehouse, N. A. Kierstead, and B. D. Garthwaite. 1997. Effect of yeast culture in the diets of early lactation dairy cows on ruminal fermentation and passage of nitrogen fractions and amino acids to the small intestine. J. Dairy Sci. 80:374-384.

Robert, J. C., B. Sloan, B. Saby, J. Mathe, G. Dumont, M. Duron, and E. Dzyzcko. 1989. Influence of dietary nitrogen content and inclusion of rumen-protected methionine and lysine on nitrogen utilization in early lactation dairy cows. Asian Australas. J. Anim. Sci. 2:544-545.

Robinson, P. H., W. Chalupa, W. Julien, H. Sato, and H. Suzuki. 1993. Effect of rumen-protected lysine and methionine on productivity of high producing dairy cows. J. Dairy Sci. 76(Suppl. 1):203. (Abstr.)

Robinson, P. H., W. Chalupa, W. Julien, H. Sato, H. Suzuki, and R. E. McQueen. 1992. Supplemental rumen-protected amino acids for early lactation dairy cows. J. Dairy Sci. 75(Suppl. 1):199. (Abstr.)

Robinson, P. H., W. Chalupa, C. J. Sniffen, W. E. Julien, H. Sato, K. Watanabe, T. Fujieda, and H. Suzuki. 1998. Ruminally protected lysine or lysine and methionine for lactating dairy cows fed a ration designed to meet requirements for microbial and postruminal protein. J. Dairy Sci. 81:1364-1373.

Rulquin, H., L. Le Henaff, and R. Vérité. 1990. Effects on milk protein yield of graded levels of lysine infused into the duodenum of dairy cows fed diets with two levels of protein. Reprod. Nutr. Dev. (Suppl. 2):238.

Rulquin, H., P. M. Pisulewski, R. Vérité, and J. Guinard. 1993. Milk production and composition as a function of postruminal lysine and methionine supply: A nutrient-response approach. Livest. Prod. Sci. 37:69-90.

Rulquin, H., and R. Vérité. 1993. Amino acid nutrition of dairy cows: Production effects and animal requirements. Page 55 in Recent Advances in Animal Production, Proc. 27th Univ. Nottingham Feed Manufacturer's Conf., P. C. Gainsworthy, ed. Nottingham University Press, Nottingham, UK.

Samuelson, D. J., S. K. Denise, R. Roffler, R. L. Ax, D. V. Armstrong, and D. F. Romagnolo. 2001. Response of Holstein and Brown Swiss cows fed alfalfa hay-based diets to supplemental methionine at two stages of lactation. J. Dairy Sci. 84:917-928.

Schwab, C. G. 1995. Protected proteins and amino acids for ruminants. Pages 115-141 in Biotechnology in Animal Feeds and Animal Feeding. R. J. Wallace and A. Chesson, ed. V. C. H. Press, Weinheim, Germany.

Schwab, C. G., C. K. Bozak, N. L. Whitehouse, and M. M. A. Mesbah. 1992a. Amino acid limitation and flow to the duodenum at four stages of lactation. I. Sequence of lysine and methionine limitation. J. Dairy Sci. 75:3486-3502.

Schwab, C. G., C. K. Bozak, N. L. Whitehouse, and V. M. Olson. 1992b. Amino acid limitation and flow to duodenum at four stages of lactation. 2. Extent of lysine limitation. J. Dairy Sci. 75:3503-3518.

Socha, M. T. 1994. Determining the methionine requirements of lactating dairy cows. Ph.D. thesis, University of New Hampshire, Durham.

Wu, Z., R. J. Fisher, C. E. Polan, and C. G. Schwab. 1997. Lactational performance of cows fed low or high ruminally undegradable protein prepartum and supplemental methionine and lysine postpartum. J. Dairy Sci. 80:722-729.

Xu, S., J. H. Harrison, W. Chalupa, C. J. Sniffen, W. Julien, H. Sato, T. Fujieda, K. Watanabe, T. Ueda, and H. Suzuki. 1998. The effect of ruminal bypass lysine and methionine on milk yield and composition of lactating cows. J. Dairy Sci. 81:1062-1077. 